\title{
A KOREAI KÖZTÁRSASÁG KERESKEDELMI POLITIKÁJA ÉS A KOREU SZABADKERESKEDELMI MEGÁLLAPODÁS
}

\author{
NESZMÉLYI GYÖRGY IVÁN \\ TRADE POLICY OF THE REPUBLIC OF KOREA \\ AND THE KOREU FREE TRADE AGREEMENT
}

\begin{abstract}
The Republic of Korea (South Korea) is one of the typical, newly-industrialised economies of Asia (ANIEs) that has undergone spectacular economic and social development over the last half century. Since the 1960 s it has developed gradually and has become one of the most advanced nations of the world.

As a result of the stalemate of the Doha-round, and of the financial and economic crisis in 2008-2009, a new trend seems to have emerged in the field of trade liberalization in the world. Instead of striving for a comprehensive, multilateral framework, a growing number of "new generation" free trade agreements have been emerging that are concluded on a bilateral level or among a few countries.

The Republic of Korea joined this trend in 2008. Since then it has concluded a number of FTAs with Asian, American, European and other partners including the USA and the European Union, and it still has a number of draft agreements under negotiation. The EU-Korea FTA (KOREU) entered into force on 1 July 2011, marking a new era in EU-Korea trade relations. It is the most comprehensive free trade agreement ever concluded by the EU, and the first with a partner country in Asia. Since it came into force, import duties have been eliminated on nearly all products ( $98.7 \%$ of duties within five years), which resulted in a far-reaching trade liberalization in services as well. Since 2011 the European Union's exports to Korea have been growing, and the former trade deficit in the EU-Korea relations has shifted to European surplus in the balance of trade. This can be seen as an advantage for the EU, but it also reflects the vulnerability of the Korean economy's competitiveness.
\end{abstract}

Keywords: Republic of Korea, Trade policy, FTA, European Union

\section{Bevezetés}

A Koreai Köztársaság (Dél-Korea) Kelet-Ázsiában, a Koreai-félsziget D-i részén helyezkedik el. $99720 \mathrm{~km}^{2}$ területe több európai országéhoz (pl. Magyarország, Portugália, Csehország) hasonló nagyságú, ugyanakkor népessége ötszöröse az említett országokénak: lakossága a CIA World Factbook 2018 júliusi adatai szerint 51418097 fő (CIA 2019).

A Koreai-félsziget az ázsiai kontinens ÉK-i részétől D-re, mintegy ezer kilométer hoszszan húzódik É-D-i irányban. É-on fóként a Kínai Népköztársasággal határos, de egy rövid szakaszon érinti Oroszországot is. 1948 óta a Koreai-félsziget - nagyjából a 38. északi szélességi fok mentén - két részre tagolódik: a Dél-Koreának is nevezett Koreai Köztársaságra, illetve a kommunista Észak-Koreára (Koreai Népi Demokratikus Köztársaság, KNDK). K-ről a Japán-, Ny-ról a Sárga-tenger határolja, DK-i partjainál található a két tengert összekötő és a Koreai-félszigetet a Japán szigetektől elválasztó Koreai-szoros, amely mindössze 170 km széles. K-en tagolatlan, meredek tengerpart szegélyezi kevés szigettel, míg D-en és Ny-on lankásabb és rendkívül tagolt a partvidék, előterében több ezer kisebb-nagyobb szigettel (1.ábra).

A félsziget K-i partja közelében, É-D-i irányú, helyenként 2000 méterig emelkedő vízválasztó hegylánc húzódik, amely K-en meredek lejtőkkel ereszkedik le a keskeny partsze- 


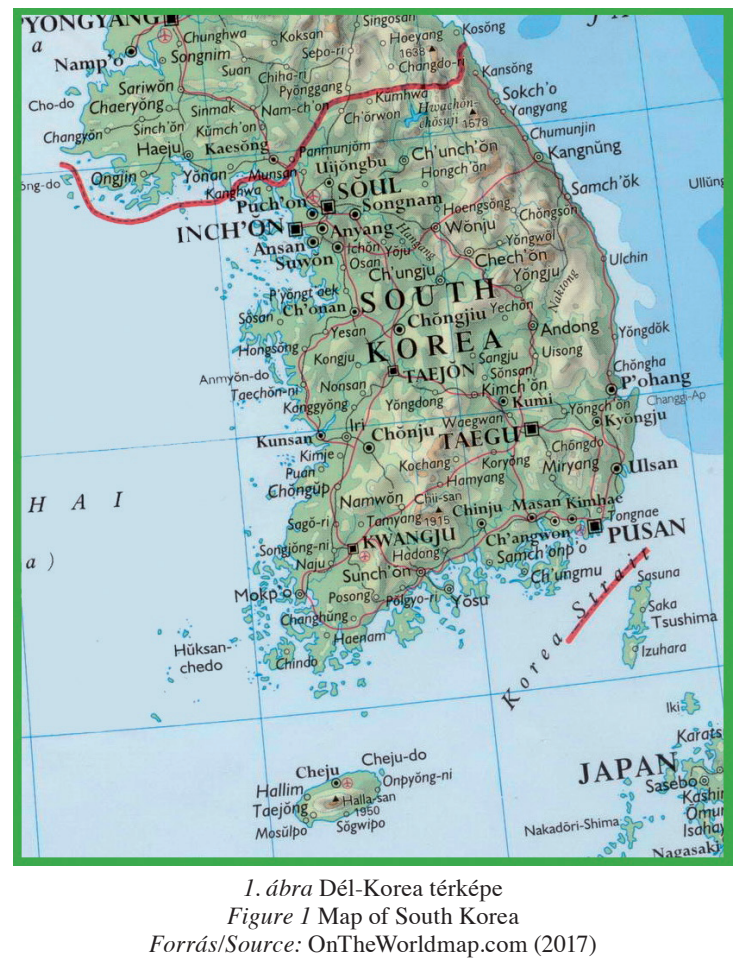

gélyhez. A hegyvidék vonulataitól Ny-ra halomvidék terül el, amely a Sárga-tenger partvidékén alacsony dombokkal övezett medencék sorozatára bomlik. A félsziget legmagasabb pontja a 2744 m-es Baekdu-san (Pektu-szan, kínaiul Changbai-san), amely Észak-Korea és Kína határán található. A Koreai Köztársaság legmagasabb pontja az 1950 m magas Halla-san, amely a Jeju- (Csedzsu-) szigeten helyezkedik el (NESZMÉLYI Gy. 2004).

Az ország területének mintegy 70\%-a hegyvidék, kiterjedtebb part menti síkságok csak Ny-on és D-en fordulnak elő. A lakosság főleg a sík részeken települt jelentősebb számban, itt a népsưrúség igen nagy. A mindössze 18,1\%-nyi (CIA, 2019) mezőgazdaságilag hasznosítható területet mintegy 2,5 millió farmer múveli. Az ipari és a szolgáltató ágazatok sikereihez képest a dél-koreai agrárium mindig is elmaradottabb volt; ma is alacsony hatékonyság és magas termelési költségek jellemzik.

Korea éghajlata mérsékelt, négy évszak váltja egymást (2.ábra), emiatt - szemben a szubtrópusi, illetve trópusi klímájú délkelet-ázsiai országokkal - itt évente csak egyszer aratnak rizst, amely Dél-Koreában is a fő termény és táplálék. A nyári hónapokban elsősorban a kelet-ázsiai monszun hatása érvényesül, télen viszont az ázsiai kontinens belseje felől hideg és igen száraz levegő áramlik be, így az évi átlagos csapadékmennyiség „,mindöszsze” 1274 mm (FAO Water Report 2012). A főváros, a tízmilliós Szöul nagyjából az északi szélesség 37 fokánál helyezkedik el, ami Athén vagy Tunisz pozíciójának felel meg, ám időjárása az említett két városhoz képest jóval szélsőségesebb; télen nem ritkán mínusz tíz fok alá süllyed a hőmérséklet, míg nyáron a gyakori és kiadós esőzések, valamint a magas páratartalom miatt a trópusi éghajlathoz hasonlít.

A tanulmány keretében a Koreai Köztársaság gazdasági fejlődésének, kereskedelmi politikájának sajátos útját és szakaszait mutatom be, különös hangsúllyal a közel tíz évvel 

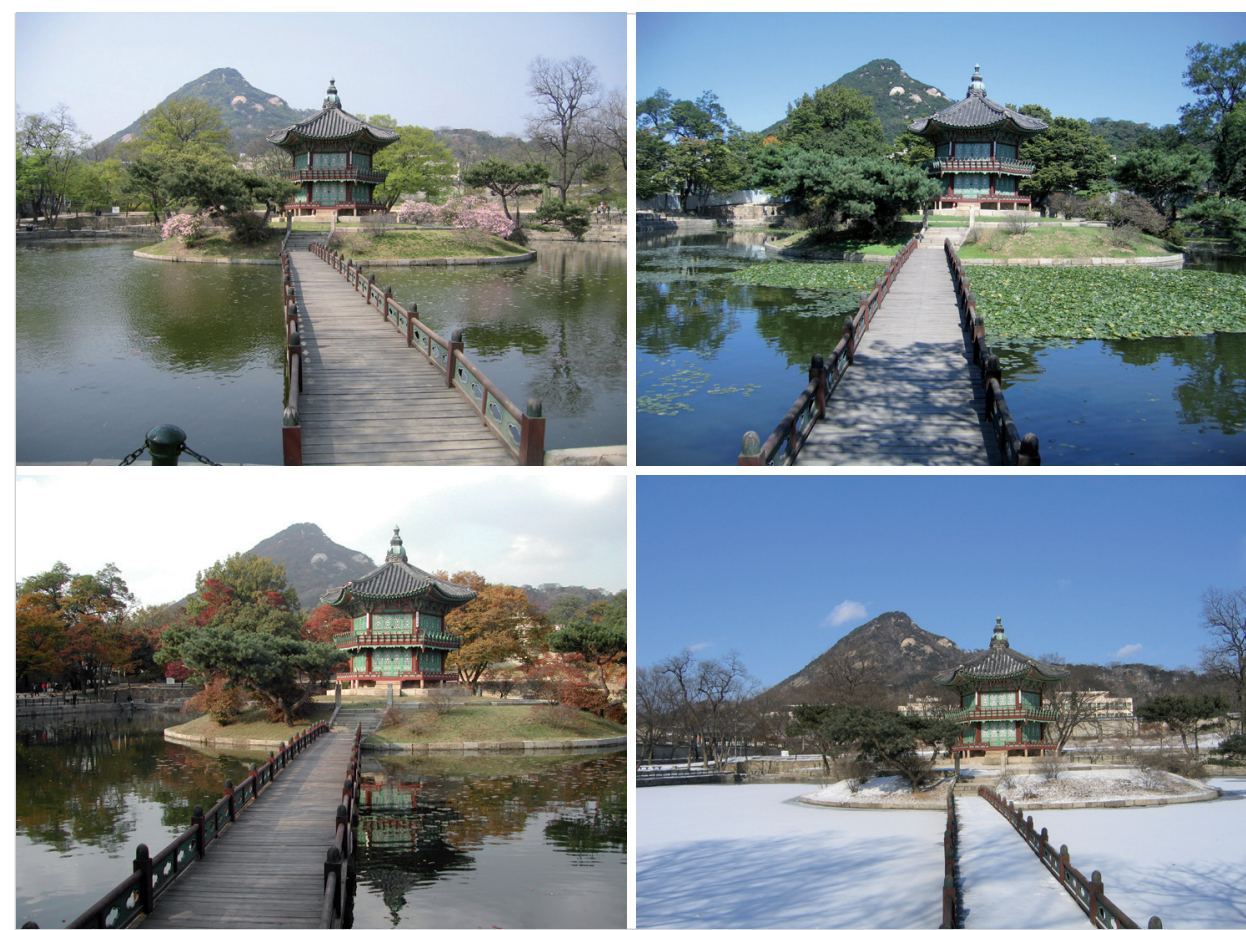

2. ábra A négy évszak Koreában (Hyangwonjeong Pavilon, Kyongbokkung, Királyi Palota, Szöul) Forrás: A szerző felvételei, 2003-2004

Figure 2 The four seasons in Korea (Hyangwonjeong Pavilon, Kyongbokkung, Royal Palace in Seoul) Source: Photo taken by the author (2003-2004)

ezelőtt aláírt Korea-EU szabadkereskedelmi megállapodásra. A tanulmány nagyrészt a BGE Keleti Üzleti Akadémia (OBIC) által támogatott, az ázsiai fejlesztési bankokról szóló, 2018. évi kutatási projekt keretében a szerző által végzett kutatások eredményeire épül, kiegészítve újabb szakirodalmi forrásokkal, illetve koreai és más nemzetközi adatbázisokból származó információkkal.

\section{Dél-Korea gazdasága}

Dél-Korea az 1960-as évek eleje óta látványos gazdasági és társadalmi fejlődésen ment, illetve megy ma is keresztül. Gazdasági erejét mutatja, hogy mind az 1997-1998. mind a 2008-2009. évi gazdasági válságból igen hamar, alig egy-két év leforgása alatt kilábalt, valutája, a dél-koreai won (KRW) és devizatartalékai stabilak.

Főként történelmi okokkal magyarázható - japán gyarmati időszak (1910-1945), a II. világháború, illetve az 1950-1953 között zajlott koreai háború -, hogy Dél-Korea még az 1960-as évek elején is a világ egyik legszegényebb országa volt. Később, az 1970-es évektől kezdődően viszont látványos és dinamikus gazdasági növekedést mutatott fel, ami az exportvezérelt ipari és szolgáltatói ágazatok teljesítményének volt köszönhető. A gazdasági növekedés évi üteme - elsősorban az 1980-as évtizedben, egészen az 1990-es évek közepéig - 8-12\%-os volt, de az 1997/98. évi regionális, illetve a 2007-2009-es világgazdasági válság közötti évek során is elérte az évi 4-6\%-ot. Az utóbbi válságból való kilábalás 
szintén viszonylag gyorsan végbement, ám lendülete már nem volt olyan energikus, mint az előző válság idején, és az ez utáni években mindössze 2-4\% között mozog.

Az 1960-as évtized elejétől 1988-ig a Koreai Köztársaságot katonai kormányzat irányította, amely az ország kitörési pontjaként az exportvezérelt gazdaságfejlesztési stratégia alkalmazását tekintette. Az erőteljes kormányzati ellenőrzésen és beavatkozáson kívül következetesen megvalósított gazdaságfejlesztési politika, illetve az ennek köszönhető látványos gazdasági növekedés kulcsfontosságú volt, emellett számos további tényező is szerepet játszott az ország felemelkedésében, mint például a magas megtakarítási és beruházási ráta, illetve a (kezdetben) olcsó munkaerô. Az ország egyike az újonnan iparosodó ázsiai gazdaságoknak (ANIEs), amely jelentős mértékben követte a japán és részben az amerikai modellt. A japán modell a II. világháború utáni időszakban kialakított sajátos gazdaságfejlesztési módszer- és eszköztár megnevezése, amely Kelet- és Délkelet-Ảzsia több gazdaságában - köztük Dél-Koreában is - meghatározóvá vált. Lényegét a szakirodalom leginkább az ún. „,fejlesztő állam” koncepciójából eredezteti, ami először JoHNSON, C. (1982) révén jelent meg a közgazdasági szakirodalomban, és nem csupán a kifejezés honosodott meg széles körben, hanem magát a fejlesztő állam jelenséget, illetve az újonnan iparosodott gazdaság mibenlétét, illetve a két fogalom egymással való összefüggését is számos kutató elemezte (pl. Douglass, M. 1994; OKITA, S. 1991), illetve terjesztette ki egyes, a kelet-ázsiai térségen kívüli országokra is (pl. BAGCHI, A. K. 2000). Japán a térség legmodernebb gazdaságaként jó minőségú, ám aránylag olcsó termékeivel komoly világpiaci sikert aratott egy kevéssé csúcstechnológiai ágazatban, majd ennek bevételeit arra használta föl, hogy szintet ugorjon, azaz nem a munkaeró-intenzív ágazatokba, hanem a technológiai fejlesztésbe, a kutatásba és az oktatásba fektette be, így jutott el néhány évtized alatt a könnyűipartól a tudásintenzív fejlesztési, tervezési, szervezési tevékenységekig, amelyek tovább erősítették az ország sikerét (GYURIS, F. 2017).

A fejlesztô állam legfontosabb ismérvei a következők: „kapitalista, tervgazdaságon alapuló modell, amelyben a fejlesztésorientált szemléletet hosszú távú elkötelezettség jellemzi, továbbá sajátja az aktív állami beavatkozás a kitûzött társadalmi-gazdasági célok elérése érdekében. Mindemellett az is hozzátartozik, hogy a fejlesztő állam kialakítása vagy fenntartása társadalmi konszenzust feltételez a fejlesztések terén az állam központi szerepének elfogadásáról, valamint a fő társadalmi-gazdasági célok tekintetében” (RICZ, J. 2016). A japán vezetés az általa alkalmazott szemléletet és modellt kezdettől el kívánta határolni mind az amerikai modelltől (ezen a viszonylag csekély állami beavatkozás mellett, szabadpiaci alapon múködő gazdaságot értve), mind a szovjet típusú tervgazdaságtól (RICZ, J. 2016; CsÁKI, Gy. 2016). Más megfogalmazással élve, a fejlesztő állam ,a kapitalista Északkelet-Ázsia politikai, bürokratikus és pénzügyi hatalmának egy darabban szőtt hálójának tömör kifejezése" (Woo-Cumings, M. 1999). Fontos aláhúzni, hogy itt nem csupán a kormányzat erőteljes beavatkozásáról van szó, hiszen az önmagában még nem feltételezi a fejlesztô állam modelljét, aminek szinte teljes ellentéte az úgynevezett járadékos állam. Például a közép-ázsiai posztszovjet országokban, amelyekben szintén erôs a gazdaság feletti állami/kormányzati befolyás, ám a jövedelem, a ,járadék” forrása nem az egyre magasabb hozzáadott-értéket képviselő munka, hanem elsősorban természeti javak, nyersanyagok értékesítése (GYENE P. 2017; VASA L. 2018).

Dél-Korea abszolút értelemben is ma már a világ egyik legnagyobb gazdasága, a folyó áron számított GDP alapján a világranglista tizenegyedik helyén áll (3. ábra). 2013-ban Park Geun-hye korábbi elnök meghirdette a „Második Csoda a Han folyó felett” programját, amelynek középpontjában az úgynevezett kreatív gazdaság programja szerepel. Az ICT (Információs és kommunikációs technológia), a hagyományos ipar és a kulturális tartalom területét érintő konvergencia új formáira irányuló utalások később is rendszeresek voltak 
a volt elnök asszony beszédeiben (CONNELL, S. 2014). A kreatív gazdaság programját kisebb változtatásokkal a jelenlegi államfö, MoON JAE-IN is megtartotta. A fejlett, tudásintenzív ipar révén az ország komoly lépéseket tett a fenntarthatóság irányába, ezek sajátos példái az ún. okos város projektek, amelyekre ma már számos példa említhetô a világban. DélKoreában zöldmezős beruházás keretében a smart megoldások teljes tárházát alkalmazó mintavárosokat alakítanak ki (pl. Songdo) (EGEDY, T. 2017).

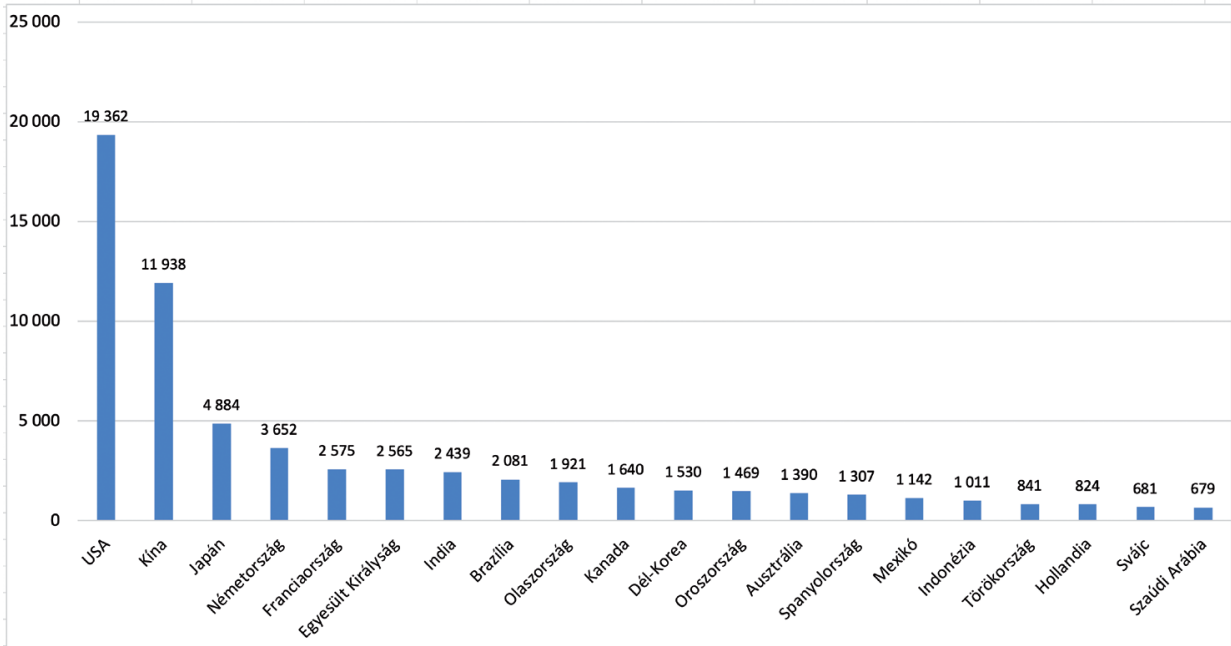

3. ábra A világ legnagyobb gazdaságai 2017-ben. - GDP toplista (milliárd USD, folyó áron) Forrás: A szerző saját szerkesztése a Statista (2018) nyomán

Figure 3 The largest economies of the world in 2017. - GDP Toplist (billion USD, current prices) Source: The author's own edition based on Statista (2018)

Más kérdés viszont, hogy a gazdaság abszolút mérete (a teljes GDP nagysága) önmagában nem tükrözi a fejlettséget, az inkább a GDP egy főre jutó értékével jellemezhető, és ha ezt nézzük, akkor a Koreai Köztársaság ma még, a hatalmas fejlődés ellenére is, az OECD országok listájának még csak az alsó felében helyezkedik el, és fontos kérdés, hogy tovább tud-e lépni.

\section{Sajátos gazdaságföldrajzi adottságok}

A két koreai állam mindmáig formálisan hadiállapotban áll egymással, a békeszerződés hiánya többek között az infrastrukturális összeköttetések mindmáig fennálló hiányosságaiban is megnyilvánul. Dél-Korea ugyan természetföldrajzi értelemben félszigeten helyezkedik el, ám szárazföldön csak Észak-Koreán keresztül vezetne út az ázsiai kontinens más részei felé, ez azonban mindmáig nem múködik. Kereskedelmi, illetve gazdaságföldrajzi szempontból tehát a Koreai Köztársaság szigetállam, hiszen a nemzetközi áruszállítás, illetve személyforgalom egyaránt vagy légi, vagy vízi úton bonyolódik. Ugyanakkor a szárazföldi, elsősorban vasúti összeköttetés megvalósítására már évtizedekkel korábban készültek tervek, különösen a 2000-es évtized első felében, a KIM DAEJUNG elnök nevével fémjelzett Napfény-politika idején. Ekkor - bő tíz évvel a Hszi CsINPING kínai államf”́ által 2013-ban meghirdetett Egy Övezet, Egy Út (OBOR) (bővebben 1. ENGELBERTH I.-SÁGI J. 2017) projektet megelőzően - már születtek koreai tervek Iron 
Silk Road (Vasúti Selyemút) néven (SoN, K. 2006), amelyek célja és lényege az volt, hogy az észak-koreai vasúthálózat felújítása, illetve az összeköttetés helyreállítása után Kínán és Oroszországon keresztül - egyszerre több alternatív vonalon - biztosítható legyen a koreai áruk vasúti szállítása Európáig (UN Report 2019).

A 4. ábra egy korabeli dél-koreai kereskedelemfejlesztési tanulmányban szereplő térképvázlat alapján azt mutatja be, hogy az Iron Silk Road projektben dél-koreai részról tulajdonképpen három alternatívával számoltak: a transzszibériai, a transzkínai és a transzmongóliai vasútvonallal. A transzszibériai vonal teljesen megkerüli Kínát, ugyanakkor a szállítási távolság jóval nagyobb, mint a transzmongóliai vasút igénybevétele esetén.

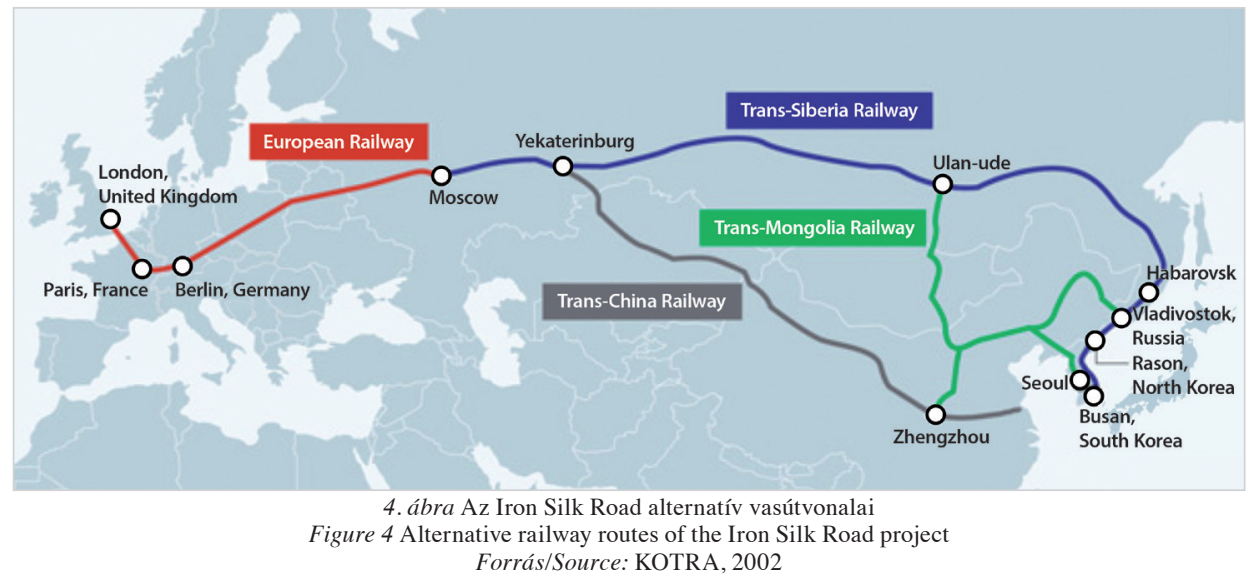

Az említett Napfény-politika jegyében más gazdasági projektek is születtek a két Korea között. Ilyen volt a Koreai-félsziget keleti részén a Hyundai Asan cég által koncesszióban felépített és néhány évig üzemelő üdülőkomplexum a KNDK-beli Gyémánt-hegységben, ahová kezdetben hajóval szállították az utasokat Dél-Koreából, ám 2004-re megvalósult a két Koreát elválasztó demilitarizált övezeten (DMZ) átvezetô közúti kapcsolat, hasonlóképpen a határhoz közeli Keszon városban létrehozott közös ipari övezet megközelítését szolgáló út is. Maga a DMZ felkeltette a természettudósokon kívül a vállalkozók érdeklōdését is, hiszen a több évtizedes katonai szembenállás miatt ez a $256 \mathrm{~km}$ hosszú és $4 \mathrm{~km}$ széles területsáv flórája és faunája - a háborítatlanság miatt - rendkívül gazdag, így az egykori belnémet határzónához hasonlóan alkalmas lehet a későbbiekben természetvédelmi és rekreációs célokra, mint a határ menti együttmúködés sajátos formájára (GÁLOSI KovÁCs B.-HoRvÁTH G. 2018). A Korea-közi kapcsolatok azonban a 2000-es évek eleje óta időről időre feszültté váltak, ezért az említett elképzelések és projektek egy része meg sem valósult, más részük pedig időközben leállt és még Moon Jae-in jelenlegi elnök, valamint KIM JONG-UN észak-koreai vezető 2018 áprilisi megbeszélésén sem sikerült ezek ügyében megállapodásra jutni. A koreai ihletésű Iron Silk Road projekt sem valósult meg, igaz, ennek Koreán kívüli részét ma Kína valósítja meg One Belt One Road néven, de a saját gazdasági érdekei mentén. Ez azt is jelenti, hogy az egyébiránt rendkívül impozáns vasútfejlesztési eredményeket (ERDEI, A.-ERDEINÉ KÉSMÁRKY-GALLY, Sz. 2018) felmutató Kína fejlesztési terveinek nem része a Korea-közi vasúti összeköttetés megteremtése és fejlesztése. Ezt továbbra is a két Koreának kell megoldania a jövőben. Ha ez megvalósul és rácsatlakozik a korszerúsített kínai hálózatra, akkor a dél-koreai vállalatok exportfeltételei logisztikai szempontból számottevően javulhatnak. 


\section{Dél-Korea kereskedelmi politikájának fejlódése}

A Koreai-félsziget kettéosztását követően az egykori japán gyarmat ipari kapacitásainak, továbbá természeti erőforrásainak, ásványkincseinek (pl. vasérc, színesfémek, feketekőszén stb.) (KőszEGI L.-K. KALAS M. 1958) döntő része északon maradt. A Koreai-félsziget déli része, a mai Koreai Köztársaság természeti erőforrásokban, energiahordozókban szegény. Ezért, valamint amiatt is, hogy a Koreai Köztársaság az 1980-as évekig igen szerény belföldi vásárlóerővel rendelkezett, a külkereskedelem szerepe kezdettől fogva nagyon fontos volt. Ebből a szempontból az egyik legjelentősebb fordulópont az 1960-as évek elején történt, amikor az ország az exportvezérelt gazdaságfejlesztés útjára lépett. A gazdasági fejlődés fő húzóerői a magántulajdonban levo, többnyire családi alapon szerveződött vállalatok voltak, amelyek mára hatalmas konglomerátumokká növekedtek (koreaiul chaeboloknak nevezik ezeket). A Koreai Köztársaság ettől fogva a nemzetközi kereskedelem liberalizációja mellett szállt síkra, elsősorban abban a reményben, hogy az kedvező körülményeket teremt a növekvő koreai export számára. Mindez nagyjából az 1980-as évekig nagy vonalakban nem is változott, a növekvő export pedig döntő mértékben járult hozzá az ország látványos gazdasági sikereihez.

Ugyanakkor, amikor Dél-Korea behozatali, illetve befelé irányuló tőkebefektetési politikájáról beszélünk, elmondható, hogy ugyanaz a kormányzat már sokkal kevésbé lelkesen támogatta a koreai belföldi piac megnyitását. Míg a koreai export valóban szárnyalt (kezdetben textilipari, majd nehéz- és vegyipari termékek, gépjármúvek, később ICT-termékek és szolgáltatások révén), addig egészen az 1990-es évek végéig - az 1997-1998. évi ázsiai pénzügyi válságig, illetve az azt követő fokozottabb piaci nyitásig - az importpolitika igen szigorú volt: a vámok mellett számos nem vámjellegú akadály is nehezítette a külföldi áruk bevitelét, például Szöul utcáin az 1980-as, 1990-es években alig lehetett látni külföldi gyártmányú autókat.

Az exportorientált,ám erôsen védett koreai gazdaság felemelkedésében jelentős szerepe volt az 1980-as évek során véghezvitt egyoldalú nyitásnak, a multilaterális kereskedelmi rendszer melletti elköteleződésnek. A GATT (Általános Vám- és Kereskedelmi Egyezmény) keretében folyó tárgyalásokkal összehangolt egyoldalú liberalizáció Dél-Korea, és mellette más kelet-ázsiai gazdaságok esetében hozzájárult a nyitáshoz, súlyuk növekedéséhez a nemzetközi kereskedelemben, valamint a gazdasági modernizáció felgyorsításához (ARMSTRONG, S. 2012).

\section{Az „új generációs” szabadkereskedelmi megállapodások}

A szakirodalomban gyakran találkozunk az „új generációs szabadkereskedelmi megállapodás" kifejezéssel, ami nagyjában-egészében azt jelenti, hogy ezek a megállapodások a partnerek között sajátos, integrált rendszer felé mutatnak, azaz nem csupán a vámokat érintő és egyes nem vámjellegú korlátozásokat építik le egymással szemben, hanem az egyszerú árucsere-forgalom ügyletein túl a befektetésekre, a szellemi tulajdon védelmére és az együttmúködés számos más területére is kiterjednek. Ebben a tekintetben érdemes felidézni NAGY, Cs. (2017) szavait, aki az új irányzattal kapcsolatban a következőket fejtette ki: „Az új generációs szabadkereskedelmi megállapodások új fejezetet nyitnak a nemzetközi gazdasági kapcsolatok terén. A nemzetközi szabadkereskedelem a 21. század egyik központi, globális kérdésévé válik úgy a róla folyó heves politikai viták miatt, mint gazdasági jelentôsége miatt...”. 
A teljesség kedvéért fontos aláhúzni, hogy a kérdéssel kapcsolatban számos, egymástól jelentősen eltérő véleménnyel találkozni kutatói és politikusi körökben egyaránt. Nincs tehát arról szó, hogy e megállapodások a korábbiakhoz viszonyított komplexitásuk okán mindenki szerint egyértelmúen kedvezőbb világgazdasági rend megalapozói lennének, amelyek eredménye egy klasszikus “win-win” szituáció. Több, különösen fejlődő országbeli elemző ellenzi az újabb, átfogó megállapodásokat, mivel szerintük ezek a kevésbé fejlett gazdaságok számára számos hátrányt okoznak. PURUGGANAN, J. (2015) szerint az új generációs kereskedelmi és befektetési megállapodások súlyos fenyegetést jelentenek a szegény és marginalizált helyzetben levő emberek életére és megélhetésére. Ezek a megállapodások messze túlmutatnak a kereskedelem liberalizálására irányuló elkötelezettségen. Számos gazdaságpolitikai elemet is magukban foglalnak, amelyek a termékek és szolgáltatások piaci liberalizációját elősegítik, amellett erôsebbek és szigorúbbak a szellemi tulajdonjog védelme tekintetében, továbbá eltörlik a befektetések útjában álló akadályokat, így a befektetők számára fokozott védelmet nyújtanak. A kritikus elemzők tehát úgy gondolják, hogy az új szabadkereskedelmi megállapodások rendszere alapvetően csak az erős gazdaságok, illetve a befektetők számára lesz előnyös, míg a gyenge vagy kevésbé fejlett gazdaságok, illetve társadalmi csoportok rosszul járnak vele. Hogy ez így lesz-e vagy sem, pontosabban, az előnyök és hátrányok kit és milyen mértékben érintenek majd, annak tudományos megítéléséhez egyelőre még hiányzik a történeti távlat.

Dél-Korea a 2000-es évek elejétól kezdett szabadkereskedelmi megállapodásokat kötni egyes fejlődő, illetve fejlett országokkal, így az előzőkben említett trend tulajdonképpen ekkor kezdődött, bár csak később, a 2008. évi válságot követően teljesedett ki. A 2000-es évek elejéig Dél-Korea nemzetközi kereskedelmi politikája összhangban állt a GATT/ WTO-val, amely a világkereskedelem liberalizációját globális dimenzióban, multilaterális keretek között tartotta kívánatosnak. Ugyanakkor ebben az időszakban már jól látható volt a WTO (World Trade Organization - Kereskedelmi Világszervezet) égisze alatt folyó multilaterális kereskedelmi tárgyalások dohai fordulójának kudarca (AMADEO, K. 2016), és ez a világ számos gazdaságát, így Dél-Koreát is más, lehetséges megoldások felé ösztönözte. Ez utóbbira látszik alternatívának az átfogó, „új generációs” két- és többoldalú szabadkereskedelmi megállapodások koncepciója (LEE, J. 2012).

Mindezek mellett az utóbbi évtizedek során a Koreai Köztársaság kereskedelmi partnereinek struktúrája jelentősen átalakult. Dél-Korea 1986. évi teljes külkereskedelmében az USA részesedése volt a legnagyobb (30,8\%), a második helyen Japán állt (24,6\%). Akkor Kína csupán 1,1\%-kal részesedett. 2011-re viszont Kína részaránya vált a legnagyobbá $(20,4 \%)$, a második helyen az ASEAN-blokk (Association of Southeast Asian Nations - Délkeletázsiai Nemzetek Szövetsége) (11,6\%), ezt követte Japán (10\%), az EU $(9,6)$ és az USA $(9,3 \%)$.

2003 szeptemberében, a dél-koreai kormány egy ún. „FTA-útitervet” jelentett be, ami gyakorlatilag nemzeti gazdasági fejlesztési menetrendnek felelt meg, és ennek köszönhető a kormányzat koncepcióváltása is: a passzív FTA-politikát aktív FTA-politika váltotta fel. Az útitervben két fontos politikai elv szerepel. Az első az, hogy Korea annyi szabadkereskedelmi megállapodást kössön rövid időn belül, amennyit csak lehet, annak érdekében, hogy visszanyerje világpiaci versenyképességét és csökkentse a koreai vállalatok alternatív költségeit. A másik az, hogy az útiterv szorgalmazza a többcsatornás és a párhuzamos szabadkereskedelmi megállapodásokra irányuló tárgyalásokat a világ nagy gazdaságaival (LEE, J. 2012).

Az ezredfordulón Dél-Korea egyike volt azon kevés kelet-ázsiai gazdaságoknak, amelyek nem rendelkeztek szabadkereskedelmi megállapodásokkal és továbbra is a (WTO égisze alatti) multilaterális kereteket részesítették előnyben. Ez az álláspont azonban változott, attól kezdődóen, hogy 2003-ban aláírták az első kétoldalú szabadkereskedelmi 
megállapodást Chile és Dél-Korea között (ArmSTRONG, S. 2012). Említést érdemel, hogy a korábbi szabadkereskedelmi megállapodások gazdasági hatásai általában korlátozottak voltak, az érzékeny ágazatok szinte mindig kivételt képeztek, és a felek törekedtek a súlyos védőintézkedések elkerülésére. Az új típusú megállapodások e tekintetben eltérőek. Korea esetében a Korea-EU szabadkereskedelmi megállapodás (KOREU) és a koreai-amerikai szabadkereskedelmi megállapodás (KORUS) jó példái annak, hogy ezek a megállapodások jelentős szerepet játszottak Dél-Korea erősen védett gépjármú és mezőgazdasági ágazatának liberalizálásában.

A KOREU és a KORUS rendelkezései, bár igen sok tekintetben hasonlóak (COOPER, H. W. et al. 2011), de több ponton el is térnek egymástól. Ilyen például a megállapodások életbe lépése utáni első hároméves időszak alatti átlagos vámcsökkentés mértéke, ami az KORUS esetében 94,5\%, míg a KOREU esetében 92\%. Mindezen túl eltérések vannak egyes ágazatok, illetve termékkategóriák tekintetében is. A KORUS például kedvezőbb feltételeket tartalmaz hústermékek és zöldségfélék szállítására, míg a KOREU a feldolgozott élelmiszerek, a vegyipari, textilipari, gépipari és elektronikai termékek szempontjából kedvezőbb. Az állati termékek esetében a különbség oka a koreai piac nagyobb fokú érzékenysége az EU irányában, míg a KOREU más termékekre vonatkozó kedvezőbb rendelkezései abból fakadtak, hogy az EU erôsen ragaszkodott a vámok minél gyorsabb ütemben való leépítéséhez (Song, Y. 2011).

Jelentős eredmény, hogy az amerikai és európai cégek számára néhány szolgáltatási ágazat is nyitottá vált. E két megállapodás révén sikerült elérni néhány érzékeny koreai ágazat védelmének fokozatos megszüntetését, beleértve a sertés-, tej- és egyéb mezőgazdasági termékek körét (a rizs kivételével). Annak ellenére, hogy a vámok leépítése az érzékeny ágazatban változó, és hosszadalmas folyamat (egyes termékek esetében akár tizenöt-húsz év is lehet), a tendencia hosszabb távon mindenképpen a vámmentes kereskedelem irányába mutat.

Korea természeti adottságai miatt, valamint az 1940-es évek végén, illetve az 1950-es évek során végrehajtott, részben politikai célokat is szolgáló földreform máig élő örökségeként a mezőgazdasági termelők többsége miniatűr és széttagolt földterületeken családi alapú gazdálkodást folytat. Ezt annak ellenére teszi, hogy ezek hosszú ideje átfogó, kétszintű szövetkezeti rendszerbe tagolódtak, többségük, különösen a rizstermesztők nem lehetnek a piacon versenyképesek komoly központi termelői támogatások és védelem nélkül (NESZMÉLYI, GY. 2017). Ezért a mezőgazdaság, azon belül is a rizs mint fő termény termesztése különösen érzékeny ágazatnak számít a dél-koreai kereskedelempolitika szemszögéből.

A dél-koreai vámszervektől (KCS 2018) származó információ szerint a Koreai Köztársaság 2017 elejéig 15 szabadkereskedelmi megállapodást kötött összesen 52 országgal (ide értve a 28 tagú Európai Uniót és a 10 ASEAN-tagot), ezek a megállapodások ratifikáltak és életbe léptek. Az EU-n és az ASEAN-on kívüli további partnerek: Chile, Szingapúr, EFTA, India, Peru, USA, Törökország, Ausztrália, Kanada, Kína, Új Zéland, Vietnám és Kolumbia.

Mindezeken túl további nyolc szabadkereskedelmi megállapodás van tárgyalási szakaszban 24 országgal, ide értve a Chilével, Indiával és az ASEAN-nal kötött korábbi megállapodások felülvizsgálatát (KCS 2018).

\section{A Koreai Köztársaság külkereskedelmének jellemzői napjainkban}

A Koreai Köztársaság 2017. évi exportja kerekítve 573,7 milliárd USD volt, míg az import összege 478,4 milliárd USD, így ezt az évet Dél-Korea mintegy 95 milliárd USD külkereskedelmimérleg-többlettel zárta. Az 1995-2016 közötti idôszakra vonatkozó export-im- 
port grafikon (5.ábra) alapján nemcsak az 1995 óta összességében bekövetkezett jelentős növekedés, valamint az 1997-1998., majd a 2008-2009. évi válság hatása látható, hanem a 2015-2016 közötti időszak visszaesése is. Ez utóbbi 2017-ben ismét növekedésbe fordult, megközelítve a 2014. évi csúcsértékeket.

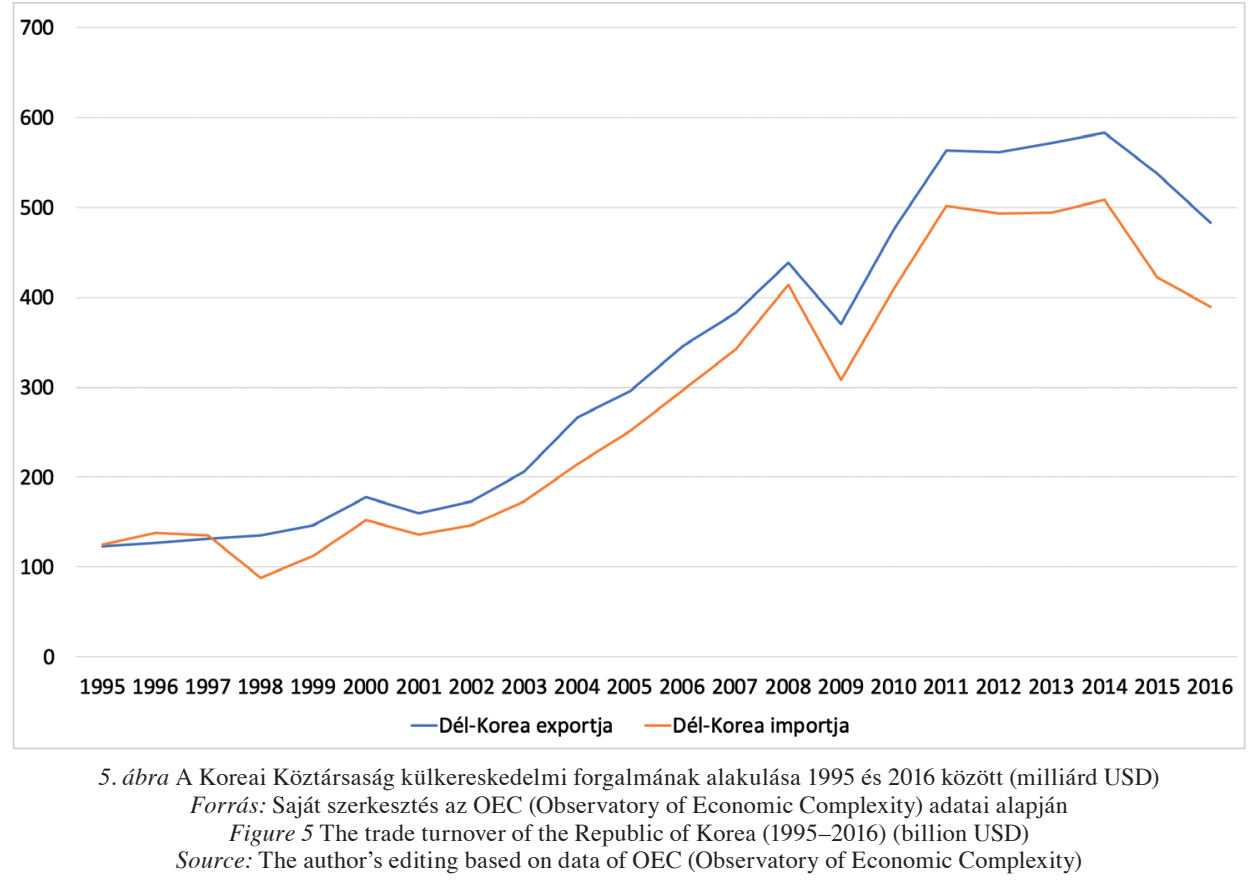

Az utóbbi évtized folyamán Dél-Korea külkereskedelmében két további fontos változás következett be. Az egyik a kereskedelmi partnerszerkezet változása, a másik pedig az exportáru-struktúra átalakulása. A Korea International Trade Association (KITA) említett adatai szerint 2017-ben a Koreai Köztársaság teljes exportja 573694 millió, összes importja 478478 millió USD volt. Az 1. és a 2. táblázat adatai alapján egyrészt az látható, hogy 2018-ra az előzó évhez képest mind az export, mind az import összege növekedett, másrészt - és ez legalább olyan lényeges -, hogy Dél-Korea legfontosabb kereskedelmi partnerei az ázsiai és csendes-óceáni térségben találhatók, az Európai Unió (28) nincs jelen a legfontosabb exportpiacok között. A legfontosabb beszállítók között is egyedül Németország szerepel; az onnan származó csaknem 21 milliárd USD import is csak 3,9\%-a Korea összes importjának.

A dél-koreai export iparági szerkezetében az utóbbi évtizedek során folyamatosan történtek változások. Az 1960-as években a dél-koreai export több mint 72\%-ban nyersanyagokat tartalmazott, majd az 1970-es évektől váltak a feldolgozóipari termékek a fó volumenhordozókká. 2011-ben például a feldolgozóipari áruk aránya már 97,2\% volt az exportban (LEE, J. 2012). A feldolgozóipari áruk kategórián belül, annak könnyű- és nehéziparra bontásán túl érdemes azt is kiemelni, hogy Dél-Korea esetében a hangsúly fokozatosan az alacsony hozzáadottérték-tartalmú árucikkek felől a magasabb hozzáadottérték-tartalom irányában változott. Azaz, míg az 1960-as években a munkaerő-intenzív termékek exportja volt a jellemző (ruha és textiláruk), a 1970-es évektől kezdődően a termelés és az 
A Koreai Köztársaság legfontosabb exportpiacai (2018)

The main export markets of the Republic of Korea (2018)

\begin{tabular}{lcc}
\hline Reláció & Összes (USD) & Részesedés (\%) \\
\hline Összesen & 604859657 & 100,00 \\
Kínai Népköztársaság & 162125055 & 26,80 \\
USA & 72719932 & 12,02 \\
Vietnám & 48622098 & 8,04 \\
Hongkong & 45996441 & 7,60 \\
Japán & 30528580 & 5,05 \\
India & 15606221 & 2,58 \\
Tajvan & 20783511 & 3,44 \\
Szingapúr & 11782182 & 1,95 \\
Mexikó & 11458233 & 1,89 \\
\hline
\end{tabular}

Forrás: saját szerkesztés a Korea International Trade Association (KITA, 2019) adatai alapján

Source: The author's editing based on data of Korea International Trade Association (KITA, 2019)

2. táblázat - Table 2

A Koreai Köztársaság legfontosabb beszállítói (2018) The main import sources of the Republic of Korea (2018)

\begin{tabular}{lcc}
\hline Reláció & Összes (USD) & Részesedés (\%) \\
\hline Összesen & 535202428 & 100,00 \\
Kínai Népköztársaság & 106488592 & 19,90 \\
USA & 58868313 & 11,00 \\
Japán & 54603749 & 10,20 \\
Szaúd Arábia & 26335761 & 4,92 \\
Vietnám & 19643385 & 3,67 \\
Ausztrália & 20718640 & 3,87 \\
Németország & 20853971 & 3,90 \\
Tajvan & 16738374 & 3,13 \\
Oroszország & 17504050 & 3,27 \\
\hline
\end{tabular}

Forrás: saját szerkesztés a Korea International Trade Association (KITA, 2019) adatai alapján

Source: The author's editing based on data of Korea International Trade Association (KITA, 2019)

export gerincét az acélipar, a hajógyártás, a gépjármúvek és a vegyipar adta (LEE, J. 2012). A hajógyártás fejlesztésében nem csupán a koreai export-expanzió felfuttatásának szándéka nyilvánult meg, hanem az is szerepet játszott, hogy a II. világháború után recesszió következett be az európai hajógyártásában, így Japán, Dél-Korea, majd Kína is megelőzte 
az öreg kontinenst, mindamellett, hogy Dél-Korea máig igen jelentős szerepet tölt be a világ hajógyártásában (IGARI A. 2018).

Az 1980-as évektől azonban a magas hozzáadott értéket tartalmazó, tudás- és technológia-intenzív áruk és szolgáltatások kerültek előtérbe (LEE, J. 2012). A Koreai Köztársaság gazdaságának további fontos ismérve a nyitottság, amit a nyitottsági mutató (a teljes külkereskedelmi forgalom és a bruttó nemzeti jövedelem aránya) szemléltet. A 6.ábrán szereplő oszlopdiagramból látható, hogy a nyitottsági mutató 2011-ig nőtt, majd azóta fokozatos csökkenést mutat, bár a 2016. évi 80,8\%-os érték még mindig azt tükrözi, hogy a délkoreai gazdaság jelentős mértékben nyitott.

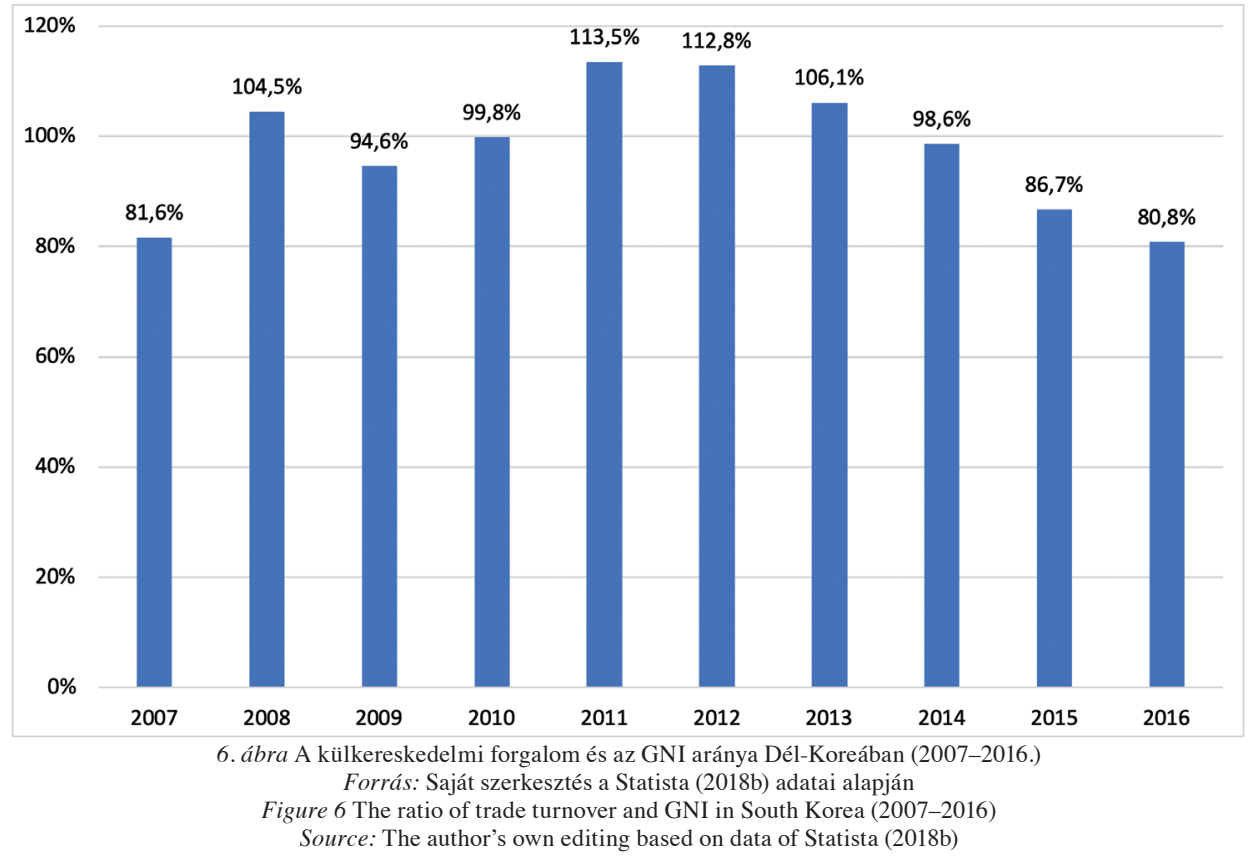

\section{A Koreai Köztársaság és az Európai Unió gazdasági és kereskedelmi kapcsolatai}

Az Európai Unió és a Koreai Köztársaság közötti szabadkereskedelmi megállapodás (KOREU) 2011. július 1-jén lépett életbe, ami az EU és Dél-Korea közötti kereskedelmi kapcsolatok új fejezetének kezdetét jelentette. A megállapodás 15 fejezetből áll, 3 jegyzőkönyvet és néhány mellékletet tartalmaz. Fő célja az áruforgalom, a szolgáltatások kereskedelme és a befektetések liberalizálása, illetve megkönnyítése, a kormányzati közbeszerzési piacok megnyitása, az e-kereskedelem előmozdítása, a két entitás közötti piaci verseny erősítése, a külföldi múködőtőke-áramlás elősegítése, valamint mindezzel egyidejúleg a szellemi tulajdonjog védelme. A két fél kötelezettséget vállalt arra, hogy eltörli a vámokat a másik entitásból származó árukra, valamint, hogy a nemzetivel azonos elbánást alkalmaz a másik féllel szemben (PAPADEMETRIOU, T. 2010).

KAREL DE GuChT, az EU akkori (2010-2014 között hivatalban levo), kereskedelmi ügyekért felelős biztosa aláhúzta, hogy a megállapodás pontot tett annak az öt éve húzódó 
folyamatnak a végére, amely az EU kommunikációjában „Global Europe in a Competing World" néven célként tűzte ki, az ázsiai térség iránt elkötelezettségének megújítását. Mindezen túl, az EU és Dél-Korea közötti szabadkereskedelmi megállapodás a leginkább ambiciózus és átfogó megállapodás azok között, amelyekről az EU valaha tárgyalt ázsiai országgal. A megállapodás célja nem csupán a kétoldalú kereskedelem és a gazdasági növekedés erősítése, hanem tágabb értelemben is kihat Ázsiára és a világ más térségeire azzal, hogy jelzi az EU üzleti célú nyitottságát harmadik országok felé, valamint elkötelezettségét a szabadkereskedelem mellett. A KOREU megállapodás az első új generációs szabadkereskedelmi megállapodás, amelyet az EU megkötött (Európai Bizottság, 2010).

Dél-Koreát mint szabadkereskedelmi partnert az EU kereskedelempolitikai stratégiája prioritásnak tekintette. A megállapodást célzó tárgyalások 2007 májusában kezdődtek meg Szöulban, amelyet nyolc tárgyalási forduló követett, majd a két fél 2009. október 15-én látta el kézjegyével a megállapodás szövegét. 2010 szeptember 16-án az Európai Unió Tanácsa jóváhagyta a megállapodást (ET 2011/265/EU Határozat), amely 2010. október 6-án az EU-Korea csúcsértekezleten került hivatalosan is aláírásra. Az Európai Unió Parlamentje 2011. február 17-én adta meg egyetértését, majd a megállapodás átmeneti rendelkezéseinek alkalmazására 2011. július 1-jétől került sor. Ennek alapján az importvámokat csaknem valamennyi árucikk esetében eltörölték (öt éves átmeneti időszak alatt a vámok 98,7\%-át), ezzel egyidejúleg a szolgáltatások kereskedelmében is messzemenő liberalizálás történt (ideértve a távközlés, a környezetvédelmi szolgáltatások, hajózás, pénzügyi és jogi szolgáltatások területét). A KOREU keretében az EU ipari, halászati és mezőgazdasági termékei jelentôsen csökkentett vámok mellett vagy vámmentesen vihetôk be Dél-Koreába. 2011. július 1-jétôl a vámok fokozatos csökkentése, majd megszüntetése a szállító vállalatok részére komoly megtakarítást jelent, amelynek összege mintegy évi 1,6 milliárd euró. A vállalatok versenyképessége szempontjából a vámok megszűnésén kívül egyre inkább a stratégiai szemléletú menedzsment válik kulcsfontosságú tényezővé, ami lehetővé teszi, hogy a vállalkozások folyamatosan és rugalmasan képesek legyenek alkalmazkodni, illetve érzékenyen reagálni a piaci környezetre (ZÉMAN, Z. et al. 2014). Ez különösen ebben a helyzetben és időszakban válik igazán fontossá a koreai vállalatok számára.

A megállapodás a WTO alapvető rendelkezéseit is magában foglalja, mint például az import, illetve export korlátozásának tilalmát, valamint a megállapodás érvénybe lépését követően bárminemú exportvám kiszabását (Európai Bizottság 2011). A KOREU megállapodás aláírását megelőzően a Dél-Korea és az EU közötti kereskedelmi forgalom nagyjából 54 milliárd EUR volt (2009), amit összességében az EU oldaláról nézve kereskedelmi deficit jellemzett (néhány termék- és szolgáltatás-kategória esetében az EU-nak stabil pozitív egyenlege volt). Az ipari és mezőgazdasági termékekre kivetett vámok 98,7\%-os leépítésére az említett ötéves időszak állt rendelkezésre, így annak határideje 2016. július 1. volt, ezt követően tehát - néhány, fôként mezőgazdasági termék kivételével - ténylegesen vámmentes kereskedelemről beszélhetünk az EU és Dél-Korea között. Ez utóbbit méltatja a már idézett forrás (Európai Bizottság 2010) is, amely szerint a KOREU a leginkább nagyratörő és a kereskedelem területét a legnagyobb mértékben lefedő megállapodás, amelyet az EU valaha megkötött.

Az Európai Külügyi Szolgálat 2016-ban nyilvánosságra hozott egy, eredetileg 2011ben készült dokumentumot (EKSZ 2016), amely a KOREU megállapodásnak az Európai Unió szemszögéből tekintett előnyeit összesíti. A teljesség igénye nélkül, ezek legfontosabb jellemzői az alábbiak:

- A vámok eltörlése az uniós ipari és mezőgazdasági áruk kivitelére. A KOREU mentesíti az EU exportőreit a Dél-Koreába szállított ipari és mezőgazdasági termékek utáni vámok megfizetése alól (1,6 milliárd eurónyi becsült megtakarítás). Ezen belül, 
például az EU gépipari exportőrei évi 450 millió, vegyipari exportőrei több mint 150 millió EUR összegú vám fizetése alól mentesülnek. Az EU agrár-exportôrei - akik stabilan jelen vannak a dél-koreai piacon, például sertéshús, whisky és tejtermék kategóriában - dél-koreai kivitelüknek korábban összesen $2 \%$-a élvezett vámmentes elbánást, a megállapodás ezekre a termékekre is eltörölte a vámokat.

- Kedvezőbb piaci hozzáférést biztosít az EU szolgáltatás-exportőrei számára. A KOREU több milliárd eurónyi új lehetőséget nyitott meg a szolgáltatói szférában érdekelt uniós vállalatok előtt. A dokumentum megemlíti, hogy a megállapodás nem csupán az azonos szintú kedvező elbánás iránti kötelezettséget rögzíti (mint pl. az USA-val kötött megállapodásban), hanem azon is túllépett azokban az ágazatokban, amelyekhez az EU-nak különleges érdekei fűződnek.

- Az elektronikai, a gyógyszeripari és az orvosi múszerek ágazataiban a nem vámjellegű akadályok kezelése. Korábban az EU-exportőrök a szórakoztató elektronikai és háztartási készülékek, köztük a televíziók, számítógépek, mikrohullámú sütők, mobiltelefon és távközlési berendezések esetében kénytelenek voltak ismétlődő, nehézkes és költséges vizsgálati és tanúsítványozási eljárásokon keresztülmenni annak érdekében, hogy termékeiket értékesíthessék Dél-Koreában. A KOREU alapján Dél-Korea általánosságban elfogadja az európai tanúsítványokat és vizsgálati eredményeket, ezért azok megismétlésére nincs szükség. A gyógyszerek és orvostechnikai eszközök EU-exportőrei részére a dél-koreai árképzési és döntési rendszer átláthatóbbá és kiszámíthatóbbá vált a megállapodás hatálybalépése óta.

- Az EU személygépkocsi-gyártók piacra jutási esélyei a dél-koreai vámok és nem vámjellegú akadályok (NTB) megszüntetésének köszönhetóen javulnak. Az autóipari ágazatban a jövőben nem lehet új, indokolatlan akadályokat emelni. Az EU-ból származó autók esetében korábban alkalmazott 8\%-os vám eltörlése azt jelenti, hogy minden egyes, Dél-Koreába exportált 25 ezer EUR értékú gépkocsi esetében 2000 EUR összegú vámfizetés takarítható meg. De még ennél is nagyobb a jelentôsége a nagyratörő „NTB csomagnak”, amellyel Dél-Korea elfogadta a nemzetközi és az EU szabványainak az egyenértékúségét minden jelentős múszaki előírás terén. Ez azt jelenti, hogy most már az EU-beli gyártók képesek értékesíteni - az EU előírásoknak megfelelő - autóikat Dél-Koreában úgy, hogy nincs szükség további vizsgálatokra, illetve honosításra. A szabályozási együittmúködés kerete egy, a megállapodás értelmében létrejött munkacsoport lesz.

- Jobb hozzáférés a kormányzati közbeszerzésekhez. Az FTA szélesebb lehetőséget biztosít a közfeladatokat érintő koncessziókra és az ún. BOT (Built-Operate-Transfer) szerződésekre meghirdetett közbeszerzési lehetőségekhez való hozzáférésre, amelyek nem tartoznak a WTO Kormányzati Közbeszerzési Megállapodás hatálya alá. Az ilyen szerződések az európai beszállítók számára fontos kereskedelmi érdeket jelentenek, amelyek ezen a területen globális szinten is vezető szerepet játszanak. Tehát a megállapodás azzal, hogy a gyakorlatban biztosítja és jogilag is garantálja, hogy európai cégek részt vehetnek ezeken a tendereken, alapvetően kedvezőbb helyzetet teremt.

- A szellemi tulajdonjog védelme. Az európai versenyképesség megőrzéséhez a szellemi tulajdonjogok (IPR) magas szintú védelme és annak megvalósítása szükséges. A KOREU tartalmaz egy átfogó fejezetet, amely szerzői jogokkal, formatervezéssel, a végrehajtással és a földrajzi árujelzésekkel (GI) kapcsolatos rendelkezéseket tartalmaz. A szerzői jogokkal kapcsolatban például a megállapodás elősegíti azt a folyamatot, hogy EU szerzői jogok birtokosai megfelelő díjazásban részesüljenek, ha az érintett zenemúvet vagy más múalkotást Dél-Koreában használnak fel. Végrehajtás 
tekintetében a megállapodás olyan korszerú rendelkezéseket foglal magában, amelyek jelentősen meghaladják a TRIPs (Agreement on Trade-related Aspects of Intellectual Property Rights - a WTO létrehozásáról szóló egyezmény részeként elfogadott, a szellemi tulajdonjogok kereskedelmi vonatkozásairól szóló megállapodás) előírásait. A koreai fogyasztók kedvelik az EU-ból származó magas minőségû agrár-élelmiszeripari termékeket, köztük a védett földrajzi árujelzésú borokat, szeszes italokat, sajtokat vagy sonkát, amelyeknek igen jó a hírnevük Dél-Koreában. A megállapodás magas szintú védelmet biztosít a kereskedelmi szempontból fontos európai földrajzi védjegyeknek, megakadályozva az azokkal való visszaélést.

- Erôs versenyszabályozás. A megállapodás tiltja és szankcionálja a felek közötti versenyt torzító, árukkal és szolgáltatásokkal kapcsolatos gyakorlatot és tranzakciókat. Ez azt jelenti, hogy versenyellenes gyakorlatok, például a kartellezés, a domináns piaci helyzettel való visszaélés, valamint a versenyellenes egyesülést az EU és DélKorea nem tolerálja és az ilyen magatartással szemben hatékony intézkedésekkel lép fel, mivel ezek fogyasztói károkhoz és magasabb árakhoz vezetnek. A megállapodás ugyancsak jogorvoslatot nyújt, illetve megszünteti a támogatások által okozott versenytorzító hatásokat, amennyire azok a nemzetközi kereskedelmet befolyásolják. Az EU és Dél-Korea szabadkereskedelmi megállapodása bizonyos típusú támogatásokra, amelyek hatása különösen torzító, külön tilalmat mond ki.

- Horizontális kötelezettségvállalások biztosítása az átláthatóság tekintetében. A szabályozási környezet átláthatóságának hiánya gyakran okozott gondot a Dél-Koreában üzleti tevékenységet végző európai vállalatoknak. Ezért fontos, hogy a megállapodás erős átláthatósági kötelezettségvállalást tartalmaz: minden olyan szabályra és rendelkezésre vonatkozik, amelynek hatálya összefügg a KOREU-ban szereplő kérdésekkel.

- Elkötelezettség a fenntartható fejlődés mellett. A KOREU megállapodás a kereskedelem mellett a fenntartható fejlődés területén is együttmúködési keretet hozott létre. Ennek részeként a felek határozott elkötelezettségüket nyilvánították ki a munkavédelmi és környezetvédelmi szabványok betartása iránt. A megállapodás az említett kötelezettségvállalások megvalósítása, betartásuk ellenőrzése céljából a civil társadalom bevonásával külön szervezeti struktúrákat hozott létre.

- A munkaügyi kérdésekre vonatkozóan a megállapodás tartalmazza az ILO (International Labour Organization - Nemzetközi Munkaügyi Szervezet) alapvető munkaügyi normák és az ILO tisztességes munkára vonatkozó programja melletti közös elkötelezettséget, beleértve mindennemú olyan konvenciót, amelyet az ILO korszerúnek tekint (pl. a megállapodásokon túlmutató alapvető munkaügyi normák). A környezet vonatkozásában a felek kötelezettséget vállaltak arra, hogy hatékonyan alkalmazzák mindazon többoldalú környezetvédelmi megállapodások előírásait, amelyeknek részesei. Ezen túlmenően a KOREU a környezetbarát termékek esetében előírja a vámok gyorsított lebontását a zöld technológiák támogatásán keresztül a fenntartható fejlődés előmozdítása érdekében.

- A viták hatékony és gyors rendezése. Az EU és Dél-Korea közötti szabadkereskedelmi megállapodás tartalmaz egy hatékony vitarendezési mechanizmust annak érdekében, hogy a vállalt kötelezettségek végrehajthatóságát biztosítsa, továbbá egy közvetítői mechanizmust a nem vámjellegú akadályokkal kapcsolatos kérdések kezelésére. Ennek a mechanizmusnak a keretében a vitás ügyekben várhatóan 120 napon belül döntés születik, az ügyek átfutása így sokkal gyorsabb lehet, mint a WTO keretében folyó eljárások esetében (Európai Bizottság 2011).

A 7. ábra az Európai Unió és a Koreai Köztársaság közötti kereskedelmi forgalom és egyenleg adatait tünteti fel. Jól látható, hogy 2006 és 2011 között (tehát, amíg a KOREU 
életbe nem lépett) az EU-nak kereskedelmi passzívuma volt Dél-Koreával szemben, jóllehet fokozatosan csökkenő mértékben. Ugyanakkor, 2012-től kezdődően 2016-ig az EU folyamatosan kereskedelmi aktívumot ért el Dél-Koreával szemben. Ez utóbbi jellegét, természetét tekintve további, alaposabb elemzésre lenne szükség, hiszen az ad valorem számított kereskedelmi forgalom és többlet nagyságát egyidejűleg számos további tényező befolyásolhatja (pl. a nettó exportárak, illetve devizaárfolyamok változásai), így ezek torzító hatását ki kellene szűrni ahhoz, hogy a KOREU megállapodásnak a kétoldalú kereskedelmi forgalomra gyakorolt hatásáról pontos képet kapjunk. Ennek előre bocsátása mellett is - a 7. ábrán szereplő diagram alapján - első látásra elmondható, hogy a változás igen látványos volt, és hogy annak előidézésében a legnagyobb valószínúség szerint a KOREU megállapodásnak nagyon lényeges szerepe volt.

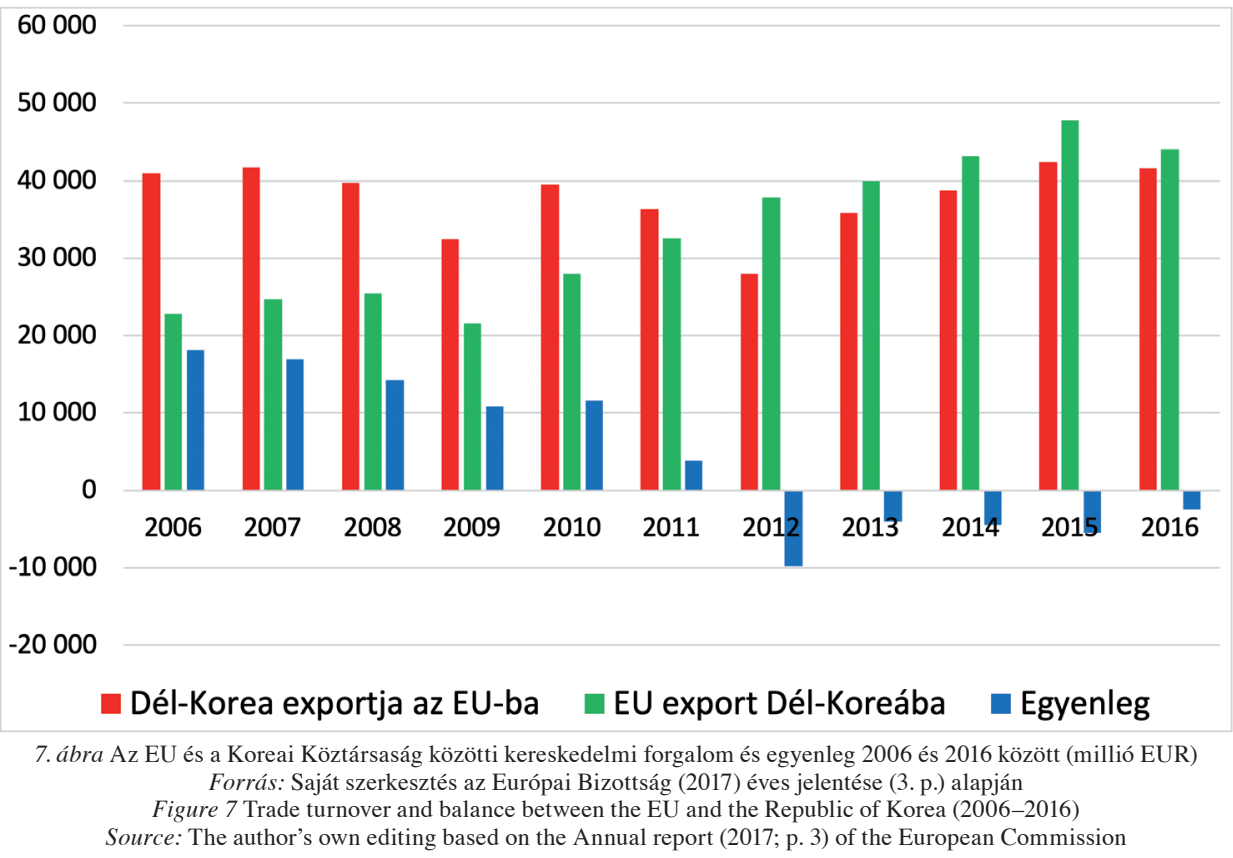

A diagramból az is jól látható, hogy míg az EU-ba irányuló dél-koreai export nagysága többé-kevésbé azonos maradt, addig az uniós export látványosan növekedett. Az EU-ba irányuló dél-koreai export, bár a vizsgált évtized alatt valamelyest ingadozott, de nem tört meg, viszont láthatóan nem is kapott új lendületet (a 2006. és a 2016. évi értékek nagyjából azonosak). Mindez egyúttal a dél-koreai gazdaság néhány krónikus, belső problémájára is rávilágít, mint például a munkaerő termelékenységével, illetve általában a dél-koreai munkaerő-piaci helyzettel kapcsolatos problémákra, amelyek nyilvánvalóan rontják a koreai gazdaság versenyképességét. Termelékenysége tekintetében a dél-koreai munkaerő az OECD-országok sereghajói között helyezkedik el. SEO, J-E. (2018) utal rá, hogy 2017-re a helyzet valamelyest javult, de a 22 tagú szervezet rangsorában (a GDP és a ledolgozott munkaórák összehasonlítása alapján) Dél-Korea még mindig csak a 17. helyen állt.

A legutóbbi években is folytatódott az a trend, amely szerint tovább bővült az Európai Unió országaiból Dél-Koreába irányuló export, illetve múködőtőke-befektetés, mint fordítva, azzal együtt, hogy az árucsere-forgalomban az EU mérlegtöbblete 2019-re eltűnt 
(a szolgáltatások terén nem). A Dél-Korea-EU kereskedelmi mérleg mára nagyjából kiegyensúlyozottá vált, Dél-Korea az EU nyolcadik, az EU pedig Dél-Korea harmadik legnagyobb exportpiaca. 2010 és 2018 között az EU Dél-Koreába irányuló exportja 88\%kal, ezen belül 2010 és 2017 között a szolgáltatásoké 77\%-kal növekedett (miközben a dél-koreai szolgáltatásexport az EU-ba 66\%-kal nőtt ugyanebben az időszakban). Az EU jelenleg Dél-Korea legnagyobb múködőtőke-befektetője, 2010-2017 között a befektetett tőkeállomány 39\%-kal növekedett (Európai Bizottság 2020).

Mindebből arra is lehetne következtetni, hogy a KOREU megállapodás Dél-Korea számára nem feltétlenül és nem minden szempontból előnyös, hiszen annak életbe lépése után kereskedelmi mérlegtöbbletét elvesztette az EU-val szemben. Itt azonban nem magában a megállapodásban kell a problémát keresni, hiszen az ugyanolyan többletelőnyöket kínál a koreai cégeknek is, mint amilyeneket az EU vállalatai élveznek, ám szemmel láthatóan az európai cégek jobban tudtak élni ezekkel az előnyökkel.

Mindehhez még érdemes azt is hozzáfüzni, hogy az Európai Uniónak a kelet-ázsiai térségben Dél-Koreán kívül csupán Japánnal van szabadkereskedelmi jellegú megállapodása (EU-Japán Gazdasági Partnerségi Megállapodás - EPA) nincs viszont Kínával - és az Egy Kína elv okán - Tajvannal sem, ami Korea számára régiós versenyelőnyként is felfogható. Hiszen mikrocsipek és más elektronikai termékek esetében Tajvan - mint az újonnan iparosodott kelet-ázsiai gazdaságok másik jellegzetes képviselője - Dél-Korea erôs versenytársa. Ugyanakkor Tajvan és az EU között az említett ok miatt közvetlenül sem beruházásvédelmi, sem szabadkereskedelmi megállapodás nincs, ezért kereskedelmi és befektetési kérdésekben minden egyes EU-tagállammal külön-külön kell tárgyalnia és megállapodnia. Ennek ellenére jelentős kereskedelmi forgalmat bonyolít az uniós országokkal, továbbá az EU 10 milliárd EUR FDI-állományával Tajvan legnagyobb múködőtőke-befektetôje (NESZMÉLYI, GY. 2017),

\section{Összefoglalás}

A Koreai Köztársaság erőteljes export-expanzión alapuló gazdaságfejlesztési politikája kezdettől fogva erósen igényelte a nemzetközi nyitottságot és a szabad piacokat, legalábbis azokban az országokban, régiókban, ahol a dél-koreai exportőrök jelen voltak vagy meg kívántak jelenni. Ugyanakkor Dél-Korea belső piacának fokozatos megnyitására csak évtizedekkel később került sor, úgy, hogy az országnak két komoly nemzetközi pénzügyi-gazdasági válságon kellett keresztülmennie, mire a dél-koreai belső piac a külföldi áruk, szolgáltatások és tőke előtt számottevő mértékben megnyílt. Dél-Korea nagyjából az ezredfordulóig globális/multilaterális keretek között támogatta a világkereskedelem liberalizációját, és csak a WTO égisze alatt folyt multilaterális kereskedelmi tárgyalások dohai fordulójának holtpontra jutását követően választott más megoldást: a fontosabb partnerekkel (EU, USA, Kanada stb.) megkötött külön-külön szabadkereskedelmi megállapodások rendszerét.

Ezek közül egyértelmúen a KOREU megállapodás a legátfogóbb, amely a vámok, továbbá a nem vámjellegú korlátozások döntő többségét egyaránt eltörölte. Mindennek elsősorban a politikai jelzésértéke lényeges és értékes. A külkereskedelmi forgalmi adatok szerint az Európai Unió és Korea egymásnak nem a legfontosabb kereskedelmi partnerei. A KOREU tényleges gazdasági jelentősége összességében tehát korlátozott lehet mindkét fél számára, hiszen valójában egy alacsony bázisról igyekszik élénkíteni a kölcsönös kereskedelmet. Az utóbbi egy, másfél évtized során azonban a Dél-Korea és az Európai Unió közötti kereskedelmi forgalom, ha alacsony bázisról is, de számottevő mértékben 
növekedett. Ez a növekedés nem feltétlenül csak a KOREU megkötésének, hanem más tényezóknek is köszönhetô, ugyanakkor, ha ez a tendencia folytatódik, akkor a KOREU pozitív szerepe gazdasági szempontból is igazolható lesz.

Az EU és Dél-Korea közötti kereskedelmi forgalom további növekedését logisztikai szempontból számottevően elősegítené a szárazföldi összeköttetés, azaz az egykori Iron Silk Road projekt felélesztése, és annak összekapcsolása a már megvalósulóban levő kínai Egy Út, Egy Övezet stratégia szárazföldi (vasúti) létesítményeivel.

\author{
NESZMÉLYI GYÖRGY \\ BGE KVIK Kereskedelem Tanszék, Budapest \\ neszmelyi.gyorgy@uni-bge.hu
}

\title{
IRODALOM
}

AmADEO, K. 2016: What Is the Doha Round of Trade Talks? - The balance - US Economy, October 27, $27,2016$.

Armstrong, S. 2012: Korea: Beyond Preferential Trade Deals Korea's Economy. pp. 35-41. http://www.keia.org/sites/default/files/publications/kei_koreaseconomy_section02.pdf

BAGCHI, A. K. 2000: The Past and the Future of the Developmental State journal of world-systems research, vi, 2, summer/fall 2000, 398-442 Special Issue: Festschrift for Immanuel Wallerstein - Part I DOI: 10.5195/ jwsr.2000.216

CHO, Y. J. 1998: The Financial Crisis in Korea: Causes and Challenges. A study of financial markets. - Graduate School of International Studies, Sogang University, Seoul, Korea. Unpublished draft, September, Asian Development Bank, Manila. 26 p.

https://aric.adb.org/pdf/aem/external/financial_market/Republic_of_Korea/korea_mac.pdf

CHor N. 2012: Impacts and main issues of the Korea-China FTA Korea's Economy. pp. 29-34. http://www.keia.org/sites/default/files/publications/kei_koreaseconomy_section02.pdf

CIA 2019: The World Factbook. - South Korea Central Intelligence Agency of the USA. https://www.cia.gov/library/publications/the-world-factbook/geos/print_ks.html

Connell, S. 2014: Building a Creative Economy in South Korea: Analyzing the Plans and Possibilities for New Economic Growth. - In: Hamisevicz, N. (ed.): On Korea 2014. Academic Paper Series, Volume 7, Korea Economic Institute of America. pp. 3-21.

Cooper, H. W.-Jurenas, R.-Platzer, M. D.-Manyin, E. M. 2011: EU-South Korea Free Trade Agreement and Its Implications for the United States. - Congressional Research Service (CRS), 2011.

CsÁKI, Gy. 2016: Developmental state, Globalization Crisis: Taiwan’s Macroeconomic Adjustment pp. 123-145. - In: KaraleKas, D. -Moldicz, Cs. (eds): Miracles Do Happen: Taiwan's Economic Development. - Budapest Business School. - University of Applied Sciences, p. 202.

Douglass, M. 1994: The 'Developmental State' and the Newly Industrialized Economies of Asia. - Environment and Planning 26, pp. 543-566, DOI: 10.1068/a260543.

EGEDY, T. 2017: Városfejlesztési paradigmák az új évezredben - A kreatív város és az okos város. - Földrajzi Közlemények 141. 3. pp. 254-262.

EKSZ 2016: Európai Külügyi Szolgálat - EU-Korea Free Trade Agreement, 18.08.2011. Vietnam Chamber of Commerce and Industry http://wtocenter.vn/content/eu-korea-free-trade-agreement

EKSZ 2016: EU-South Korea Free Trade Agreement EU-South Korea Free Trade Agreement. - 10 Key Benefits For The European Union (June 2011) European External Action Service (EEAS) 26/06/2016 https://eeas.europa.eu/headquarters/headquarters-homepage/4206/10-key-benefits-eu-south-korea-free-trade-agreement_en

ENGELBERTh I.-SÁGi J. 2017: Az Új selyemút kezdeményezés szerepe, céljai. - Külügyi Szemle 3. pp. 85-104.

ERdei, A.-ERdeiné KÉSMÁRKI-GALLY, Sz. 2018: Development of China's railway connections in the $21^{\text {th }}$ century. - In: NESZMÉLYI, Gy. I. (szerk.): Regional integration and spatial processes in the world. Szent István Egyetemi Kiadó, Gödöllő. pp. 27-41.

Európai Bizottság (Council of the European Union), hivatalos honlapja South Korea - Trade picture (Dél-Korea, Kereskedelmi helyzetkép), 2020. április 23. https://ec.europa.eu/trade/policy/countries-and-regions/countries/south-korea/ The EU and Japan's Economic Partnership Agreement (2020. január 31.) https://ec.europa.eu/trade/policy/in-focus/eu-japan-economic-partnership-agreement/

Európai Bizottság (European Commission) 2010: EU and South Korea sign free trade deal (European Commission, Brussels, 6 October 2010) http://trade.ec.europa.eu/doclib/press/index.cfm?id=626 
Európai Bizottság (European Commission) 2011: EU-Korea Free Trade Agreement in practice Publications Office of the European Union, Luxembourg, 2011. ISBN 978-92-79-20841-6 doi:10.2781/3033; 20 p. http://trade.ec.europa.eu/doclib/docs/2011/october/tradoc_148303.pdf

Európai Bizottság (European Commission) 2017: Annual Report on the Implementation of the EU-Korea Free Trade Agreement European Commission, Brussels, 20.10.2017, 12 p. http://eur-lex.europa.eu/legal-content/EN/TXT/PDF/?uri=CELEX:52017DC0614\&from=EN

Európai Bizottság 2011: Az EU Hivatalos közlönye (Official Journal of the European Union), Vol. 54, 14 May, 2011ET 2011/265/EU Határozat (2011 - A Európai Unió Tanácsa Határozata az egyrészről az Európai Unió és tagállamai és másrészről a Koreai Köztársaság közötti szabadkereskedelmi megállapodásnak az Európai Unió nevében történő aláírásáról és ideiglenes alkalmazásáról (2011/265/EU - 2010. szeptember 16.) 1,2011.5.14. https://eur-lex.europa.eu/resource.html?uri=cellar:a2fb2aa6-c85d-4223-9880-403cc5c1daa2.0005.02/ DOC_1\&format=PDF

Európai Bizottság 2011: EU-Korea Free Trade Agreement in practice Publications Office of the European Union, Luxembourg, 2011. ISBN 978-92-79-20841-6 doi:10.2781/3033; 20 p. http://trade.ec.europa.eu/doclib/docs/2011/october/tradoc_148303.pdf

Európai Bizottság 2017: Annual Report on the Implementation of the EU-Korea Free Trade Agreement European Commission, Brussels, 20.10.2017, 12 p. http://eur-lex.europa.eu/legal-content/EN/TXT/PDF/?uri=CELEX:52017DC0614\&from=EN

Európai Bizottság, (European Commission) - European Union, Trade in goods with South Korea European Commission, Directorate-General for Trade, Brussels, 17.11.2017. 10 p. http://trade.ec.europa.eu/doclib/docs/2006/september/tradoc_113448.pdf

European Union, Trade in goods with South Korea European Commission, Directorate-General for Trade, Brussels, 17.11.2017. 10 p. http://trade.ec.europa.eu/doclib/docs/2006/september/tradoc_113448.pdf

Eurostat 2019: South Korea-EU - trade in goods 2019 március https://ec.europa.eu/eurostat/statistics-explained/index.php/South_Korea-EU_-_trade_in_goods

EU-South Korea Free Trade Agreement EU-South Korea Free Trade Agreement - 10 Key Benefits 10 Key Benefits For The European Union (June 2011) European External Action Service (EEAS) 26/06/2016 https:// eeas.europa.eu/headquarters/headquarters-homepage/4206/10-key-benefits-eu-south-korea-free-trade-agreement_enFact sheet: 10 key benefits of the EU-South Korea FTA European Commission, Brussels, July, 2011, 4 p. http://trade.ec.europa.eu/doclib/docs/2010/october/tradoc_146695.pdf

Free trade Agreement between the European Union and its Member States, on the one part, and the Republic of Korea, on the other part. - Official Journal of the European Union, Vol 54, L127, 14 May 2011, pp. 6 - 1417 pp. http://eur-lex.europa.eu/legal-content/EN/TXT/PDF/?uri=OJ:L:2011:127:FULL\&from=EN

GÁLOSI KovÁCs B.-HoRVÁTH G. 2018: Határokon átnyúló természetvédelmi területek lehetőségei és problémái. - Földrajzi Közlemények 142. 4. pp. 309-327. https://doi.org/10.32643/fk.142.4.4

Griffin, C.-Christy, P. 2014: Why American Foreign Aid Works Real Clear World, $17^{\text {th }}$ April, 2014 https://www.realclearworld.com/articles/2014/04/17/why_american_foreign_aid_works.html

GyENE P. 2017: Független államiság a posztszovjet Közép-Ázsiában. - Aposztróf, 296 p. ISBN: 978-6155604-51-5

GYURIS F. 2017: A kínai gazdasági csoda okai és korlátai. - Földrajzi Közlemények 141. 3. pp. $275-287$. https://www.thebalance.com/what-is-the-doha-round-of-trade-talks-3306365

IGARI A. 2018: A tengerparti régiók változó gazdasági szerepe a 21. századi Európában. - Földrajzi Közlemények 142. 3. pp. 177-188.

Johnson, C. 1982: MITI and the Japanese Miracle. The Growth of Industrial Policy, 1925-1975. - Stanford University Press, Stanford, California.

KARP, P. 2018: Trans-Pacific Partnership revived after 11 nations agree to trade deal - without US. Guardian, January, 23, 2018. https://www.theguardian.com/world/2018/jan/24/trans-pacific-partnership-revived-after-11-nations-agree-to-trade-deal

KCS 2018: Korean Customs Service FTA Trend in Korea - „YesFTA site”. http://www.customs.go.kr/kcshome/ main/content/ContentView.do?contentId=CONTENT_ID_000002320\&layoutMenuNo=23225

Korea Customs Service (KCS) 2018: FTA Trend in Korea - „YesFTA site”. http://www.customs.go.kr/kcshome/ main/content/ContentView.do?contentId=CONTENT_ID_000002320\&layoutMenuNo=23225

Korea International Trade Association (KITA) 2019: http://www.kita.org/kStat/byCount_AllCount.do

KőSZEGI L.-K. KALAS M. 1958: Korea gazdasági földrajza. - Földrajzi Közlemények 1. pp. 62-85.

KOTRA 2002: La lettre du Kotra Septembre 2002 Centre Coréen du Commerce Extérieur et des Investissements https://france-coree.pagesperso-orange.fr/kotra/kotra_ltr_02_09.htm

KwaK, H. 1994: Changing Trade Policy and its Impact on TFP in the Republic of Korea. - The Developing Economies, XXXII-4 (December, 1994) pp. 398-422.

http://www.ide.go.jp/library/English/Publish/Periodicals/De/pdf/94_04_03.pdf 
LEE, J. 2012: Korea's trade structure and its policy challenges Korea's Economy 2012; pp. 21-28. http://www.keia.org/sites/default/files/publications/kei_koreaseconomy_section02.pdf

NAGY, Cs. I. 2017: Free trade, public interest and reality: new generation free trade agreements and national regulatory sovereignty Federal Markets “Momentum” Research Group (Hungarian Academy of Sciences, University of Szeged), $4^{\text {th }}$ May, 2017. http://mta.hu/data/dokumentumok/meghivok/20170504_Free_trade_conference.pdf

NesZMÉlyi Gy. 2004.: A Három Egykori Királyság Földje (A Koreai Köztársaság társadalmi, gazdasági sajátosságai és élelmiszergazdasága). - Agroinform 143 p. ISBN: 9635028288.

NeszméLyi, Gy. 2017: The Challenges of Economic and Agricultural Developments of Taiwan: Comparison with South Korea. - Tribun EU s. r. o., Brno, 2017, ISBN: 978-80-263-1331-1. 151 p.

Observatory of Economic Complexity (OEC) - (South) Korea Profile https://atlas.media.mit.edu/en/profile/country/kor/

OKiтA, S. 1991: Japan's Role in Asia-Pacific Cooperation The Annals of the American Academy of Political and Social Science Vol. 513, Japan's External Economic Relations: Japanese Perspectives (Jan., 1991), pp. 25-37 https://www.jstor.org/stable/1047078?read-now=1\&seq=13\#page_scan_tab_contents

PAPAdEmetriou, T. 2010: European Union; South Korea: Free Trade Agreement Library of Congress. - Global Legal Monitor, September 27, 2010 http://www.loc.gov/law/foreign-news/article/european-union-south-korea-free-trade-agreement/

Purugganan, J. 2015: New Generation Free Trade Agreements: A Threat to Life and Livelihoods Focus on the Global South, $17^{\text {th }}$ April 2015

https://focusweb.org/content/new-generation-free-trade-agreements-threat-life-and-livelihoods

RicZ, J. 2016. Developmental states in the $21^{\text {st }}$ century: Analytical structure of a new approach. - Centre for Economic and Regional Studies of the Hungarian Academy of Sciences Institute of World Economics, Working paper, No. 223. p. 33.

SEO, J-E. 2018: Korea's labor productivity ranks low in the OECD Korea JoongAng Daily, 07.05.2018. http://koreajoongangdaily.joins.com/news/article/article.aspx?aid=3047785

Son, KEY-YOUNG 2006: South Korean Engagement Policies and North Korea: Identities, Norms and the Sunshine Policy. - Routledge, 2006, 272 p.

SonG, J-A. 2018: Disappointing 2018 sales forecast dents Hyundai and Kia Financial Times, $2^{\text {nd }}$ January, 2018 https://www.ft.com/content/cc450f3e-ef72-11e7-b220-857e26d1aca4

Song, YeOnG-KWAn 2011: KORUS FTA vs. Korea-EU FTA: Why the Differences? - KEI Academic Paper Series, Korean Economic Institute, 2011, 15 p. https://core.ac.uk/download/pdf/51174858.pdf

Statista 2018a: The Statistics Portal. - Gross domestic product (GDP) ranking by country 2017. https://www.statista.com/statistics/268173/countries-with-the-largest-gross-domestic-product-gdp/

Statista 2018b: The Statistics Portal, - South Korea's dependency on foreign trade 2007-2016. https://www.statista.com/statistics/642175/south-korea-foreign-trade-share/

Strengthening Transport Connectivity Between the Republic of Korea and Europe Through the UNESCAP Eurasian Transport Corridors

https://www.unescap.org/sites/default/files/Strengthening\%20transport\%20connectivity\%20between\%20 the $\% 20$ Republic $\% 20$ of $\% 20$ Korea\%20and\%20Europe $\% 20$ through $\% 20$ the $\% 20$ UNESCAP\%20Eurasian\% 20transport\%20corridors-Full\%20Text.pdf

U.S.-Korea Free Trade Agreement (KORUS). - https://2016.export.gov/FTA/korea/index.asp

UN Report 2019: Strengthening Transport Connectivity Between the Republic of Korea and Europe Through the UNESCAP Eurasian Transport Corridors.

https://www.unescap.org/sites/default/files/Strengthening\%20transport\%20connectivity\%20between $\% 20$ the $\% 20$ Republic $\% 20$ of $\% 20$ Korea $\% 20$ and $\% 20$ Europe $\% 20$ through $\% 20$ the $\% 20$ UNESCAP $\% 20$ Eurasian $\%$ 20transport\%20corridors-Full\%20Text.pdf

VASA L. 2018. A kazah gazdaság növekedési kilátásai a modernizációs folyamatok kontextusában. - KKI Elemzések 49. pp. 1-14.

Woo-Cumings, M. (ed.) 1999: The Developmental State. -Cornell, New York.

Workman, D. 2018: South Korea's Top Trading Partners $9^{\text {th }}$ February, 2018. http://www.worldstopexports.com/south-koreas-top-import-partners/

ZÉmAN, Z.-SZABÓ, Z.-BÁRCZI, J. 2014: ar Controlling aspects of risk management. Controller Info Studies, Copy \& Consulting and Unio Publishing, Budapest, ISBN 978-9ó3-08-9751, pp. 186-197. 